\title{
Impact of Financial Crisis on Textile Industry in Pakistan
}

\author{
${ }^{*}$ Faisal Abbas ${ }^{1}$, Muhammad Tahir ${ }^{1}$, Muti Ur Rehman², Aslam Perviz ${ }^{1}$ \\ ${ }^{1}$ Imperial College of Business Studies Lahore, Pakistan \\ 2University of Sargodha, Sargodha, Pakistan \\ *faisalabbaspcc@gmail.com
}

\begin{abstract}
The aim of study is to analyze the performance of Textile sector in Pakistan covering the pre-crisis period, post crisis period and period of crisis as well. For this purpose data were collected from overall textile sector from available sources for the period of five years. According to the most of the analysts, financial crisis 2008-09 is serious one after the world wide great depression of 1930's. The analyses have been conducted on the basis of financial ratios (Profitability, liquidity and activity). The profitability ratios such as returns on assets were affected by financial crisis because returns on asset were decreased in crisis period as compared to cover pre and post crisis and same is the situation of return on equity that was also affected by financial crisis. The earnings per share are also reduced in financial crisis period because before and after crisis earning per share was positive but negative in crisis. The liquidity of this sector was also affected by financial crisis. Turnover of the assets also proved that assets were poorly managed by textile sector in financial crisis period. The results showed that the performance of textile sector had been better in pre-crisis and post-crisis while it was bad during crisis period.
\end{abstract}

Key words: Financial performance, financial crisis, Textile industry

\section{Introduction}

The main purpose of this study is to analyze the overall performance of the textile sector in Pakistan for the period of five years (2006-2010). This is the main industry of the Pakistan which is contributing the foreign 7 exchange by promoting export to the different countries. This is also the objective of the study to analyze the textile sector in the most crucial period of the crisis either decreased its performance or not. The main collapse of US banking sector have widely affected the whole world as for as finance is concerned. This is really a big problem for under developing countries.) Before starting discussion on impact of financial crisis 2008-09 on textile sector in Pakistan, it is necessary that to discuss the textile industry in Pakistan. Pakistan is populated country and having high demand for textile products. Pakistan is having four seasons in a year and all other natural resources. There was no industrial setup at the time of start of Pakistan but later in 1950 Pakistan's businessmen purchased machinery for textile sector. That led to establishment of Colony Textile Mills Limited in Multan, Kohinoor at Rawalpindi, Nishat, and Cresent Textile in Faisalabad, Star Textile Mills Limited, and Gul Ahmed Textile Mills Limited in Karachi. Textile sector is also facing problem of energy so many units are closed by the businessman. According to the Pakistan Credit Rating Agency Limited, Pakistan has an integrated textile industry comprising Cotton Spinning (Yarn), (at present it comprises 521 textile units) Cotton Weaving (cloth), (its comprises on Mill segment and Power loom units) Cotton fabric, Fabric Processing, Home Textiles, Towels, (there are 7500 towel looms in the country) Hosiery and Knitwear (there are 12000 knitting machines spread all over the country) and Apparel. According to the Pakistan Credit Rating Agency Limited, Pakistan is the fourth largest producer of cotton with the third largest spinning capacity in Asia after China and India.

To manage and control purpose of this large sector, there are some regulatory authorities in Pakistan which are working according to their limitations. To meet up the above objectives, Ministry of Textile Industry was established in September 2004, the main function of this ministry was to formulate of the textile policy, coordination with Federal Agencies, Provincial Govt. entities for the promotion of textile sector. Federal Textile Board was established for the assistance of ministry. Another special body is here for the coordination between the industry and government is called Textile Commissioners Organization (TCO). At present the 
sector has following textile SROs, which are representing the different textile segments. All Pakistan Textile Processing Mills Association (APTPMA) was established in 1991 for the promotion of processing of textile dying and printing. The association has 475 member units. All Pakistan Textile mills Association (APTMA) founded in 1952 shows the textile spinning, weaving, and composite mills. Pakistan Yarn Merchant Association (PYMA), Established in1960 for the protection of stakeholder's interest in trading of yarn is key objective. All Pakistan Textile Exporters Association (PTEA), established in 1985 by the name of All Pakistan Cloth Exporters Association and so many such types of association are working in Pakistan for the development of textile sector. In the history of crisis, this is almost considered the second one after the World Great Depression of 1929-1930. History and past experiences explained that crisis created different types of all level problems for the economy. Mainly crisis was about finance and every business needs finance for its growth, if there is no finance, there is no business. This was occurred due the collapse of the financial institutions in USA. In short, we can say that no one sector is free from the financial crisis of 2008-09. The impact of crises is clearly affecting the every sector of the economy. In this study, we have focused on the impact of financial crises on the textile industry which is main source of export of the country. We want to prove with the help of financial data of textile sector how the performance of the sector is affected during the financial crisis.

The objective of the study is to analyze the impact of financial crisis on the financial performance of the textile sector on yearly basis from 2006 to 2010. Another objective of this study is to provide information to the decision makers about their weaknesses regarding the performance. It will make sure that this will be managed in future how to deal with such type of crisis issue for this rapidly growing sector.

\section{Literature Review}

There are not enough researches made by researchers on textile sector by using the variables such like Return on Assets, Return on Equity, Return on Capital Employed Ratio, Assets Turnover Ratio and earnings per share for the performance of the textile industry in Pakistan. (There is another important point is that no enough literature is available about the same sector or industry that's why literature is taken from different sectors about financial crisis.) We have selected the literature review on the basis of variables used by researcher for analyzing the performance of the different sectors including textile. According to Channar \& Ram, (2011) Article on textile industry with the name of impact of financial crisis on the textile industry by using the same variables. They used following ratios for analysis of financial performance of the textile industry liquidity ratio, Assets Management Ratios, Debit Management Ratio and profitability Ratios and concluded that industry was performing well before financial crisis as compared to performance after the financial crisis. Khan \& Khan (2010) explains in his study Pakistan Textile Industry Facing New Challenges "Industry is facing great decline in its growth rate. The major reasons for this decline can be the global recession, the high cost of production due to increase in the energy costs etc. Depreciation of Pakistani rupee that significantly raised the cost of imported inputs, rise in inflation rate, and high cost of financing has also effected seriously the growth in the textile industry". Usman (2010) in his study Global Financial Crisis: Its impact on developing countries and lessons for Pakistan explain that the financial crisis creates a serious problem for Pakistan in its economy. The purpose of this study is to "highlighting the salient aspects of the global crisis, its impact on developing countries and drawing lessons for Pakistan. Alam (2011) in his study Impact of Financial Crisis on Textile Industry of Pakistan: Evidence from Faisalabad. "The findings of the study confirm that financial crisis and energy crisis enhanced the equity ratio of many firms and they were lesser likely to survive in international markets."

Pimple (2009) in his study Global financial crisis "Now more than ever we must be bold in these times of crisis, when we are tempted to look inward, it is precisely the time when we must move pursuit of the common good to the top of the agenda. While recently we have heard much in the US about how problems on Wall Street are affecting innocent people on Main Street, we need to think more about those about those people around the world with no streets". Mohamudally-Boolaky \& Ramlal (2009) "The paper investigates the extent to which global financial crisis has been affecting the Mauritian Financial Services sector, more particularly the Banking sector. Although the crisis started out in 2008, Mauritius experienced a lagged effect and started to face significant consequences. The measures deployed to withstand the crisis are oriented 
towards a combined strategy of increasing cash and investing in stocks." Zhao et al., (2010) in his study The Impact of Financial Crisis on Textile Trade Pattern between China and ASEAN "after the 2008 financial crisis the impact of the crisis on the trade pattern of textile industry as a whole and each of the 4 subfields (raw materials, textiles, clothing and textile machinery). G-L index and the export-import unit value ratio are analyzed with Brown-Mood median test, and the results show that the China-ASEAN trade pattern has not changed fundamentally". Gupta (2011) in the study of ADBI. The Current State of Financial and Regulatory Frameworks in Asian Economies: The Case of India "The global crisis resulted in significant tightening in the market, equity, foreign exchange, and credit markets. The crisis was also transmitted to the real sector as output, employment, and capital formation were adversely affected. In particular, the SME sector was negatively impacted from a fall in demand and reduced access to credit."

\section{Hypothesis:}

- Financial crisis decreases the return on assets and equity of textile sector.

- Financial crisis decreases earning per share of textile sector.

- Financial crisis declines the overall performance of textile sector.

\section{Methodology}

Data collection: The basic and most important element of research was data and the true data provide true and reliable results. For the purpose of this true result of this research, we had collected secondary data of textiles sector for the period of five years 2006 to 2010 from financial statements of the textile mills and analysis report of the State Bank of Pakistan (SBP). Because the data of this sector as whole was not available from any other reliable source.

Sampling Design: The entire textile sector was selected for the purpose of analysis of the financial performance of this sector for the period of five years 2006 to 2010 on the basis of financial ratios. In business the ratio analyses were almost considered a very reliable tool especially for the analysis of financial performance of the any industry or organization. For this reason, we had selected the following ratios for the purpose of analyses as under:

- $\quad$ Return on assets (ROA)

- Return on equity (ROE)

- Assets Turnover Raito(ATR)

- Debt Equity Ratio (DER)

- Earnings per share (EPS)

- Net Profit Ratio (NPR)/NP to Sales ratio

- External debts to total assets ratio

- Current ratio

- Inventory turnover ratio

- Fixed assets turnover

\section{Results and Analysis}

To analyze the performance of textile sector from 2007 to 2010 on the basis of different accounting ratios by covering different prospective of the textile sector. We have analyzed the liquidity ratios, asset management ratios or activity ratios, debt management ratios and profitability ratios.

\section{Year wise Comparison of textile sector on the basis of different financial ratios}

Table 1: Return on Assets (ROA)

\begin{tabular}{llllll}
\hline Years & $\mathbf{2 0 0 6}$ & $\mathbf{2 0 0 7}$ & $\mathbf{2 0 0 8}$ & $\mathbf{2 0 0 9}$ & $\mathbf{2 0 1 0}$ \\
\hline ROA & 3.628 & 1.065 & -1.926 & -1.281 & 3.947 \\
\hline
\end{tabular}

Source :( complied from financial statement analysis of the non financial sector by SBP, 2006-10.) 


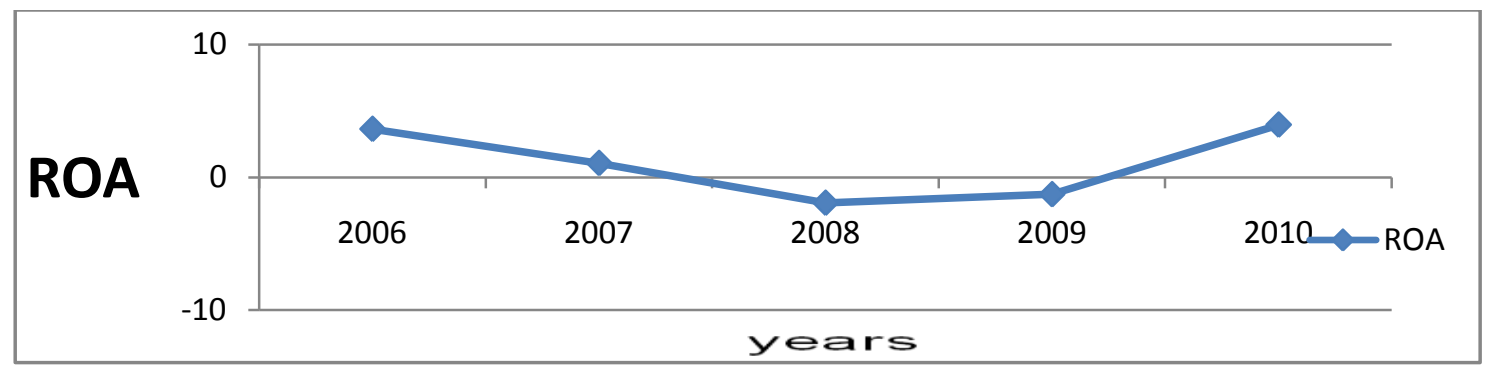

By testing the hypotheses 1 it is accepted because the return on asset decreases in financial crisis period. The above table \& diagram shows that the return on assets of the textile sector in 2006 was $3.628 \%$ on profit after, in $20071.065 \%$ this was the period of before crises and in 2008 and 2009 suddenly due to financial crises the profit of this sector converted into losses and the whole sector suffer with the loss percentage of in $(-1.926),(-1.281)$ and after the crisis in 2010 it again converting into profit 3.947\%. This trend of profit and losses clearly identify that the performance of textile sector was better before and after financial crisis.

Table 2: Return on Equity (ROE)

\begin{tabular}{llllll}
\hline Years & $\mathbf{2 0 0 6}$ & $\mathbf{2 0 0 7}$ & $\mathbf{2 0 0 8}$ & $\mathbf{2 0 0 9}$ & $\mathbf{2 0 1 0}$ \\
\hline ROE & 5.155 & 2.889 & -5.922 & -4.162 & 10.998 \\
\hline
\end{tabular}

Source :( complied from financial statement analysis of the non financial sector by SBP, 2006-10.)

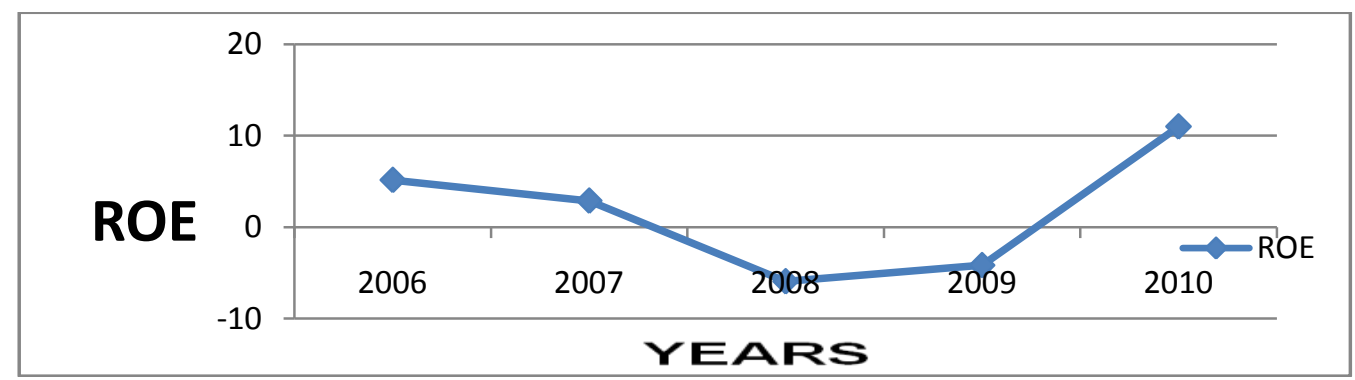

The above table \& diagram shows that the return on equity of the textile sector in 2006 was $5.155 \%$ on profit after, in $20072.889 \%$ this was the period of before crises and in 2008 and 2009 suddenly due to financial crises the profit of this sector converted into losses and the whole sector suffer with the loss percentage of in (-5.922), (-4.162) and after the crisis in 2010 it again converting into profit 10.998\%. This trend of profit and losses clearly identify that the performance of textile sector was better before and after financial crisis.

Table 3: Net Profit Ratio (NPR)/NP to Sales ratio

\begin{tabular}{llllll}
\hline Years & $\mathbf{2 0 0 6}$ & $\mathbf{2 0 0 7}$ & $\mathbf{2 0 0 8}$ & $\mathbf{2 0 0 9}$ & $\mathbf{2 0 1 0}$ \\
\hline NP Margin & 2.422 & 1.413 & -2.502 & -1.641 & 4.698 \\
\hline
\end{tabular}

Source: (compiled from financial statement analysis of the non financial sector by SBP, 2006-10.)

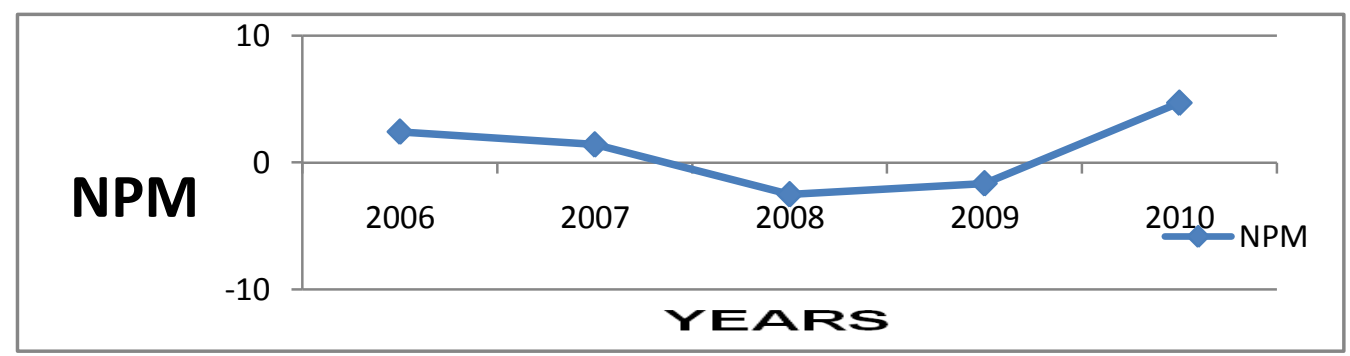


The table 3 and above diagram represent the trend of net profit on sales in which the net profit ration in 2006 was $2.422 \%$ and in $20071.413 \%$ while after this in 2008-09 during crisis profits converted into losses with the percentage of $(-2.502 \%) \&(-1.641)$ but after financial crisis it again losses of textile sector converted into profit in 20104.698.

Table 4: External debts to total assets ratio

\begin{tabular}{llllll}
\hline Years & $\mathbf{2 0 0 6}$ & $\mathbf{2 0 0 7}$ & $\mathbf{2 0 0 8}$ & $\mathbf{2 0 0 9}$ & $\mathbf{2 0 1 0}$ \\
\hline ED to TAR & 64.267 & 63.139 & 67.483 & 69.227 & 64.109 \\
\hline
\end{tabular}

Source: (compiled from financial statement analysis of the non financial sector by SBP, 2006-10.)

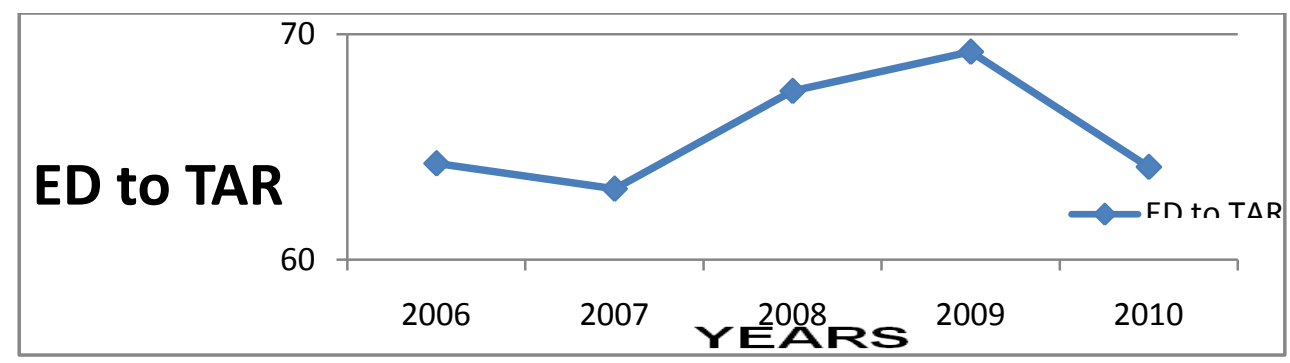

The debt ratio of this sector comparing with total assets in 2006 was $64.267 \%$ and in 200763.139 but in the period of financial crisis it gone up to 69.227 and after that in 2010 again reduce to $64.109 \%$.

Table 5: Debt to equity ratio

\begin{tabular}{llllll}
\hline Years & $\mathbf{2 0 0 6}$ & $\mathbf{2 0 0 7}$ & $\mathbf{2 0 0 8}$ & $\mathbf{2 0 0 9}$ & $\mathbf{2 0 1 0}$ \\
\hline Debt to equity ratio & 279.855 & 271.291 & 307.534 & 324.964 & 278.620 \\
\hline
\end{tabular}

Source: compiled from financial statement analysis of the non financial sector by SBP, 2006-10.

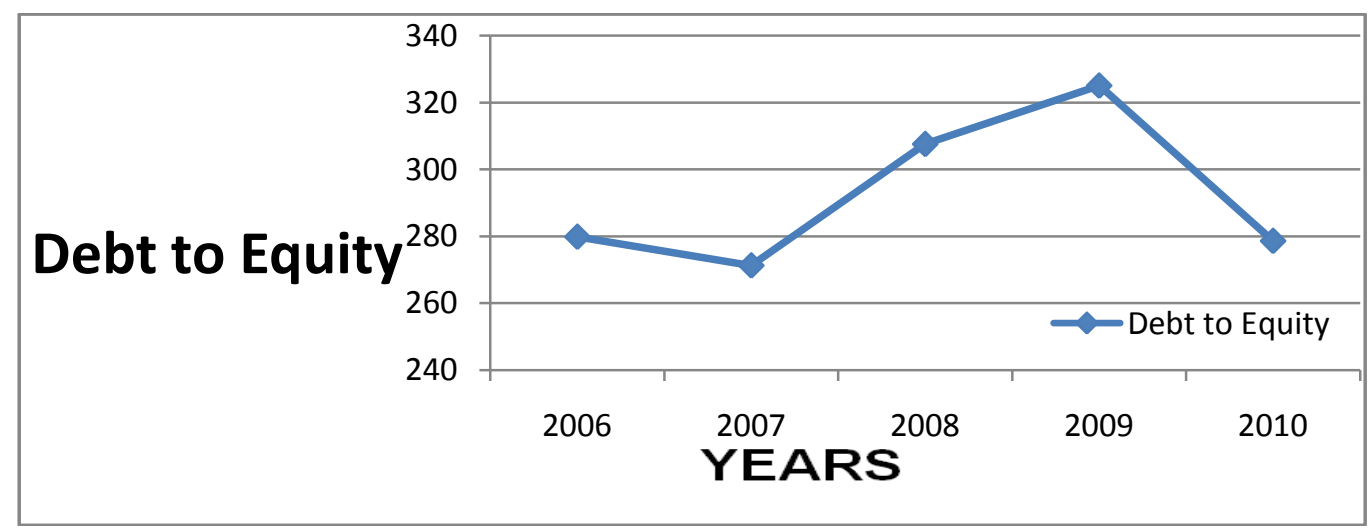

Table 5 and above diagram shows the trend of debts to equity ratio which indicates debts are how much of the equity. If we observe the trend debts were $279.855 \%$ of equity in 2006 but during crisis it was gone up to $324.964 \%$ of equity which is much higher than ratio of before crisis period. After the crisis it was again reduce to $278.620 \%$ in 2010 .

Table 6: Current ratio

\begin{tabular}{llllll}
\hline Years & $\mathbf{2 0 0 6}$ & $\mathbf{2 0 0 7}$ & $\mathbf{2 0 0 8}$ & $\mathbf{2 0 0 9}$ & $\mathbf{2 0 1 0}$ \\
\hline Current ratio & 10.792 & 1.099 & 1.107 & 0.858 & 0.928 \\
\hline
\end{tabular}

Source: compiled from financial statement analysis of the non financial sector by SBP, 2006-10. 


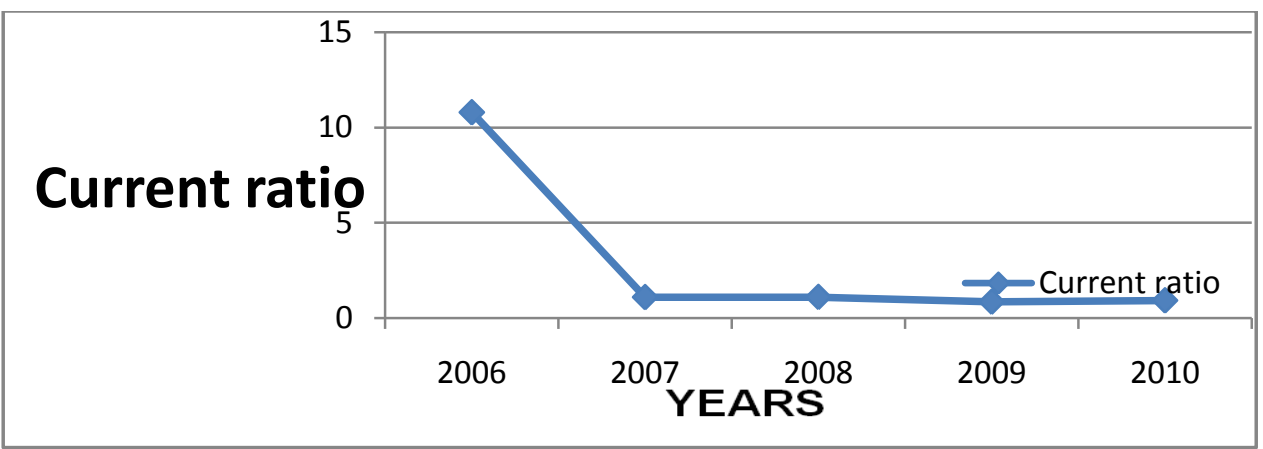

This table shows the liquidity position of textile sector from 2006 to 2010 in which the year 2006 was exceptionally outstanding liquidity by rupee 10 for the payment of rupee 1 . Although during crisis especially in 2009 this decrease to rupees 0.858 against the payment of rupee 1 which is yet not recovered by this sector in 2010

Table 7: Inventory turnover ratio

\begin{tabular}{llllll}
\hline Years & $\mathbf{2 0 0 6}$ & $\mathbf{2 0 0 7}$ & $\mathbf{2 0 0 8}$ & $\mathbf{2 0 0 9}$ & $\mathbf{2 0 1 0}$ \\
\hline ITO & 2.461 & 2.772 & 2.692 & 2.638 & 2.982 \\
\hline
\end{tabular}

Source: compiled from financial statement analysis of the non financial sector by SBP, 2006-10.

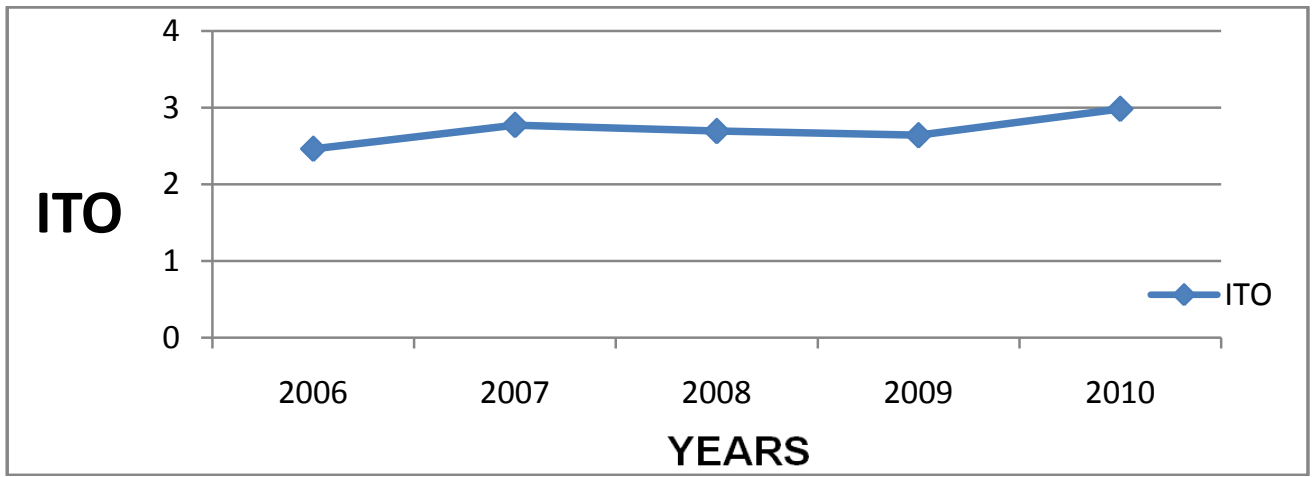

Inventory turnover ratio show that it decreases in the financial crisis but not so much there was a little variation in the management of inventory. Point to be noted here from 2006 to 2010 the inventory turnover remain in the figure of 2 .

Table 8: Fixed assets turnover

\begin{tabular}{llllll}
\hline Years & $\mathbf{2 0 0 6}$ & $\mathbf{2 0 0 7}$ & $\mathbf{2 0 0 8}$ & $\mathbf{2 0 0 9}$ & $\mathbf{2 0 1 0}$ \\
\hline FAT & 1.498 & 1.563 & 1.738 & 0.556 & 2.142 \\
\hline
\end{tabular}

Source: compiled from financial statement analysis of the non financial sector by SBP, 2006-10.

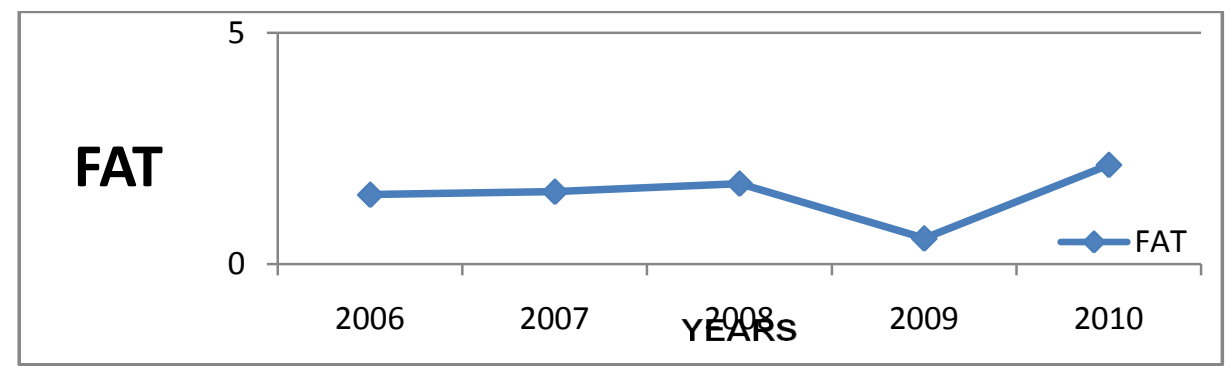


Table 8 shows the fixed assets turnover was 1.498\% in 2006, 1.563 in 2007 and 1.738 in 2008 but in financial crisis period 2009 it decrease to 0.556 and again this sector recover fixed asset turnover from 0.556 to 2.142 in 2010 .

Table 9: Total assets turnover ratio

\begin{tabular}{llllll}
\hline Years & $\mathbf{2 0 0 6}$ & $\mathbf{2 0 0 7}$ & $\mathbf{2 0 0 8}$ & $\mathbf{2 0 0 9}$ & $\mathbf{2 0 1 0}$ \\
\hline TAT & 0.761 & 0.754 & 0.770 & 0.780 & 0.840 \\
\hline
\end{tabular}

Source: compiled from financial statement analysis of the non financial sector by SBP, 2006-10.

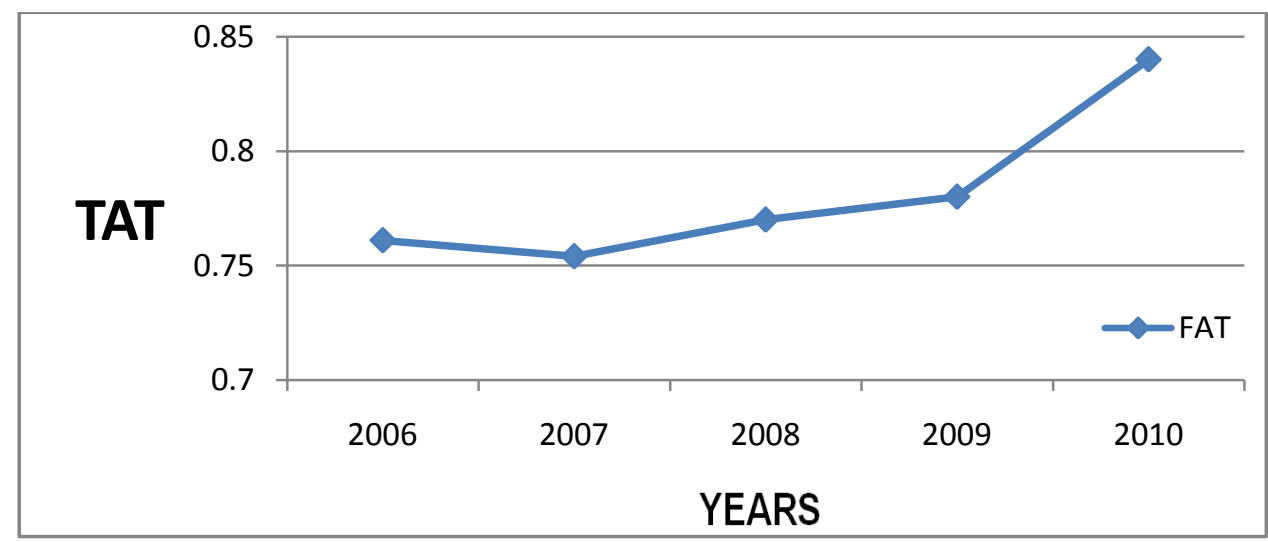

Above table shows the turnover on total assets is almost consistent from 2006 to 2009 before and during crisis but increase after the crisis in 2010. This trend indicates the use of assets is improving.

Table 10: Earning per share (EPS)

\begin{tabular}{llllll}
\hline Years & $\mathbf{2 0 0 6}$ & $\mathbf{2 0 0 7}$ & $\mathbf{2 0 0 8}$ & $\mathbf{2 0 0 9}$ & $\mathbf{2 0 1 0}$ \\
\hline EPS & 1.85 & 1.26 & -2.15 & -1.51 & 4.91 \\
\hline
\end{tabular}

Source: (compiled from financial statement analysis of the non financial sector by SBP, 2006-10.)

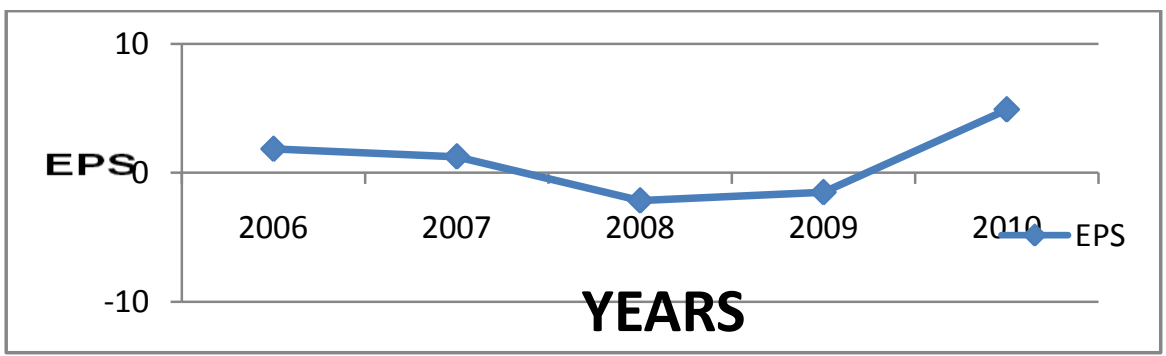

Table 10 represents the trend of earning per share of the textile sector from 2006 to 2010 . The earnings per share of this sector were RS. 1.85 in 2006, Rs. 1.26 in 2007, but in period of crisis it will converted into losses and in 2008 \& 2009 the loss per share was Rs. -2.15, Rs. -1.51 respectively. But after the crisis earning of the textile sector improves from loss to profit Rs. 4.91 in 2010 that is higher in the past five year's period.

Table 11: Analysis of overall results of the study

\begin{tabular}{llllll}
\hline Years & $\mathbf{2 0 0 6}$ & $\mathbf{2 0 0 7}$ & $\mathbf{2 0 0 8}$ & $\mathbf{2 0 0 9}$ & $\mathbf{2 0 1 0}$ \\
\hline ROA & 3.628 & 1.065 & -1.926 & -1.281 & 3.947 \\
ROE & 5.155 & 2.889 & -5.922 & -4.162 & 10.998 \\
NP Margin & 2.422 & 1.413 & -2.502 & -1.641 & 4.698 \\
\hline
\end{tabular}




\begin{tabular}{llllll}
\hline ED to TAR & 64.267 & 63.139 & 67.483 & 69.227 & 64.109 \\
Debt to equity ratio & 279.855 & 271.291 & 307.534 & 324.964 & 278.620 \\
Current ratio & 10.792 & 1.099 & 1.107 & 0.858 & 0.928 \\
ITO & 2.461 & 2.772 & 2.692 & 2.638 & 2.982 \\
FAT & 1.498 & 1.563 & 1.738 & 0.556 & 2.142 \\
TAT & 0.761 & 0.754 & 0.770 & 0.780 & 0.840 \\
EPS & 1.85 & 1.26 & -2.15 & -1.51 & 4.91 \\
\hline
\end{tabular}

\section{Conclusion and Recommendations}

The main purpose of this study is to contribute in the gap of literature on the financial performance of textile sector in Pakistan. The finding of this study may help the manager of industrial sector towards decision making about unexpected events. This study also provides information to the industrial thinker to understand the activities which are required strategic planning for the improvement of financial performance of textile sector in a bad period. After analyzing the above data by using different ratios we concluded that the hypotheses one is accepted because the return on asset and equity decreases in financial crisis, Second hypotheses is also accepted because the earning per share of the textile sector decreases in the financial crisis period. By observing the all other results it is found that the overall performance of the textile sector also decreases. It is clear after the calculation of all ratios such as return on assets (ROA), return on equity (ROE), assets turnover ratio (ATR), debt equity ratio (DER), earning per share (EPS), net profit ratio (NPR)/NP to sales ratio, external debts to total assets ratio, current ratio, Inventory turnover ratio and fixed assets turnover the performance of textile sector will not remain consistent according to each of above ratio. In other words we can say that financial crisis badly affects the sales, cost of sales, receivables, payables, fixed assets, and equity of the textile sector. We have used data for five years from 2006 to 2010 two years before crisis and one year after crisis the data of 2011 were not available at present. Future researchers may conduct research by adding the data of 2011 that will represent different results.

\section{References}

Channar, A. Z. \& Ram, N. (2011). Impact of Financial Crisis on the Textile Industry of Pakistan: A case Study of Fateh Textile Industry. Australian Journal of Basic and applied sciences, 5(10), 1435-1443.

Khan, A. A. \& Khan, M. (2010). Pakistan Textile Industry Facing New Challenges. Research Journal of International Studies, 14, 21-29.

Usman, M. (2010). Global Financial Crisis: Its impact on developing countries and lessons for Pakistan. IPRI Journal, 10(1), 93-118.

Alam, I. (2011). Impact of Financial Crisis on Textile Industry of Pakistan: Evidence from Faisalabad." South Asia Network of Economic Research Institute working paper.

Pimple, M. (2009). Global financial crisis. UN Millennium campaign.

Mohamudally-Boolaky, A. \& Ramlal, I. (2010). The Impact of the Global Financial Crisis on the Mauritian Financial Services Sector. International Research Symposium in Service Management working paper.

Zhao, Y., Fu, W., Wei, Y. \& Chen, L (2010). The Impact of Financial Crisis on Textile Trade Pattern between China and ASEAN. International Economic Studies, 36(1), 1-8.

Gupta, S. A. (2011). The Current State of Financial and Regulatory Frameworks in Asian Economies: The Case of India. ADBI Working Paper Series BP. (2006-2010). Financial Statement Analysis of the Financial Sector. Pakistan.

The Pakistan Credit Rating Agency Limited. (2011). Sector Study Textile Sector- Financial Year 2011, Www.pacra.com 